\title{
Antifungal effect of Nirgundi (Vitex nigundo) crude extracts on medically important Candida spp.
}

\author{
Usha Patil \\ Sri Jayendra Saraswathi Ayurveda College and Hospital, Nazaratpettai, Chennai, India 600123 \\ Address for correspondence: Dr.Usha Patil , M.D., Ph.D. (Ayu.), Associate Professor:
}

\begin{abstract}
:
Fungal infections are emerging as major threat especially in immune compromised patients in developing countries including India. Availability, effectiveness and cost are the major constraints in effective treatment of fungal infections in modern medicines. Nirundi (Vitex nigundo) is one of the anti-infective medicinal herb mentioned in ayurvedic literature. Antifungal effect of aqueous, ethanol, methanol and chloroform extract of $V$. nigundo dried leaf powder was investigated against clinical isolates of Candida albicans and Candida tropicalis. It was observed in the study that $C$. albicans could be effectively inhibited by ethanol, methanol and chloroform extracts while growth of $C$. tropicalis isolates could be effectively inhibited only by the chloroform extract of the $V$. nigundo. Results of the study suggest that medicinal plant mentioned in ayurvedic literature V.nigudo has the potential to be developed as antifungal drug.
\end{abstract}

\section{Introduction:}

In developing countries like India infectious diseases caused by bacteria, fungi, viruses and parasites are still a major threat to public health, due to poor health care facilities especially in rural areas. Recent emergence of antimicrobial resistance has created a renewed interest in researchers for identification of newer antimicrobial molecules from natural sources. Though several methods have suggested for finding newer anti-infective drugs, use of use of ethnopharmacological knowledge can reduce the time and energy with enhanced probability of identification of novel antimicrobial molecules. Ancient Indian literatures have detailed description of several medicinal plant materials with their antimicrobial effect in various disease conditions.

In addition to viral and bacterial infections, fungal infestations are also considered major health hazard in under developed world and in developing countries like, India. Application of topical antifungal agents, like, nystatin, miconazole, fluconazole, itraconazole and amphotericin B is the most common approach to treat fungal infections. Less number of effective antifungal agents, toxicity, resistance and cost are the major issues faced during the antifungal therapy. Hence, the effort to identify newer antifungal agents is the urgent priority for effective treatment and management of infections due to fungal pathogens. Medicinal plants having antifungal activity have been extensively reported in ayurvedic literature and these substances need to be evaluated suing in vitro antimicrobial assays as per the modern test requirements.

In ayurvedic literature drugs used in treatment of diseases conditions like, Kushta, Krimija shira shoola, krimija rhudroga etc have been described as Krimighna Dravyas (Charka samhita vimana sthana chapter 7, Shuruta Samhita uttara tantra chapter 54, Astanga Hruda chapter 20) Bathing, douching and topical preparations of krimigna dravyas have been described for treatmen of various infectious diseases.

Nirgundi (Vitex nigundo) swarasa along with arenda thail is indicated in katishoola (Vaidhyamanorama). Nirgundi thail is indicated in nadi vhrona, pama, apache, sarva vhrana (Chakradatta). Ghee cooked with nirgundi leaves said to cures kaphaga swasa and kphag kasa ${ }^{1,2}$. Recent studies have reported the antiinflammatory and analgesic ${ }^{3}$, cytotoxic ${ }^{4}$, antifeedant and antibacterial ${ }^{5}$, anticonvulsant ${ }^{6}$, estrogenic ${ }^{7}$, 
antifungal $^{8}$, hepatoprotective ${ }^{9}$, scavenging ${ }^{10}$, apoptotic ${ }^{11}$ activity in different extracts of Vitex nigundo. However reports on antifungal activity of this plant against clinical isolates of fungal pathogens are scanty.

\section{MATERIALS AND METHODS}

\section{Preliminary phytochemical analysis}

Preliminary phytochemical analysis like, detection of tannins, alkaloids, saponins, cardiac glycosides, anthroquinone glycosides, steroids, resins and volatile oils was done for qualitative assessment of phytoconstituents as per the standard protocols mentioned in Trease and Evans (1983) ${ }^{12}$.

\section{Extraction drug from the powdered plant material}

Extraction of active constituent from powdered Vitex nigundo was as per the standard procedures published elsewhere. Aqueous extraction was done using 20 grams of air dried powder in soxhlet apparatus for $12 \mathrm{hrs,}$ while ethanolic, methanolic and chloroform extraction was accomplished by immersing each of 100 grams of powdered drug in ten times the volume of $80 \%$ ethanol, methanol or chloroform respectively and allowed for cold percolation on magnetic stirrer for $24 \mathrm{hrs}$. The extracts were first filtered through double layer of muslin cloth and then with Whatman filter paper No.1. The filtrate was air dried under low heat of $50^{\circ} \mathrm{C}$ once entire diluent was evaporated the powder was weighted to calculate the yield. The extract diluted to predetermined concentration was stored at $-20^{0} \mathrm{C}$ till further use.

\section{Isolation and identification of fungal pathogens}

Candida albicans and Candida tropicalis were isolated from the clinical samples submitted to Department of Medical Microbiology, Christian Medical College (CMC), Ludhiana, Punjab. Isolates were identified based on colony morphology and staining characters as per the standard protocols mentioned in Berge's Manual of Systematic Bacteriology $(1984)^{13}$.

\section{Testing the antifungal activity of plant extracts}

Antifungal activity of the plant extracts was done following the standard disc diffusion method or dilution method mentioned elsewhere. Fungal isolates were aseptically inoculated on Sabouraud dextrose agar plates and incubated at $31^{\circ} \mathrm{C}$ for $48 \mathrm{~h}$. The colonies were suspended in sterilized $0.9 \%$ sodium chloride solution (normal saline), which was compared with McFarland solution. One $\mathrm{ml}$ of yeast suspension in normal saline was added to $74 \mathrm{ml}$ of sterile medium, to give concentration of $2 \times 10^{7}$ cells $/ \mathrm{ml}$.

\section{Viability count}

Antifungal activity of different extracts was determined by a viable colony count. Nine hundred microliter of a suspension of $10^{8}$ fungi $/ \mathrm{ml}$ was added to $100 \mu \mathrm{l}$ of plant extract and incubated at $37^{\circ} \mathrm{C}$ in shaker incubator for $60 \mathrm{~min}$. Similarly, positive bacteria control was kept in each experiment in which isolates were diluted in DMSO. Following incubation serial ten fold dilution was made in Nutrient Broth $\left(10^{-1}\right.$ through $\left.10^{-4}\right)$ and suspension from the last dilution was spread on to SDA plates and incubated as described above. Following incubation number of colonies in each plate was counted colony forming unit (CFU) per plate. The effectiveness of the plant at killing fungal isolates was expressed as percentage inhibition of colony growth (i.e. percentage of fungi killed) compared to the control.

\section{RESULTS AND DISCUSSION}

Qualitative phytochemical analysis for tannins alkaloids, saponins, cardiac glycosides, steroids: trpenoids and flavonoids showed negative results (data not shown). These test results confirm the authenticity of the drugs collected for the present study and the results were in accordance with the previously published standard observations.

Aqueous extract of nirgundi showed moderate inhibition on C. albicans while showing mild inhibition of C. tropicalis isolates tested. Ethanol extract showed significant inhibition of $C$. albicans while no inhition was observed on C. tropicalis fungal isolates. Methanol extract showed significant inhibition of C. albicans while showed mild inhibition of C.tropicalis fungal isolates. Chloroform extract showed complete inhibition of both C.albicans and C.tropicalis fungal isolates tested (Table 1). 
In immunocompromised patients (with AIDS, cancer, or organ transplant) opportunistic fungal infections, mainly resulting from Candida, Cryptococcus, and Aspergillus are life-threatening. In the present study based on ayurvedic literatures Nirgundi (Vitex nigundo) was selected to study its effect on important fungi of medical importance. Being a significant cause of hospital-acquired infection, Candida sp have also showing increased resistance to traditional antifungal agents in recent times. Identification of newer phytoconstituents with antifungal activity will help for the effective therapy of drug resistant and newly emerging fungal pathogens.

Though in vitro results of the present study suggest the potential of the drug as antifungal agent the same may not be translated into clinical effectiveness. Additionally, studies are needed to understand the specific phytoconstituents responsible for the observed antifungal activity to understand the mechanism behind he observed anti-candida activity.

Table 1: Antifungal activity (percentage inhibition) of different crude extracts of Nirgundi (Vitex nigundo)

\begin{tabular}{|c|l|l|l|}
\hline Sl.No. & Plant material & Candida albicans & Candida tropicalis \\
\hline 1. & Aqueous & $50 \%$ & $25 \%$ \\
\hline 2. & Ethanol & $75 \%$ & $0 \%$ \\
\hline 3. & Methanol & $75 \%$ & $25 \%$ \\
\hline 4. & Chloroform & $100 \%$ & $100 \%$ \\
\hline 5. & Fungi control & $0 \%$ & $0 \%$ \\
\hline 6. & DMSO control & $0 \%$ & $0 \%$ \\
\hline
\end{tabular}

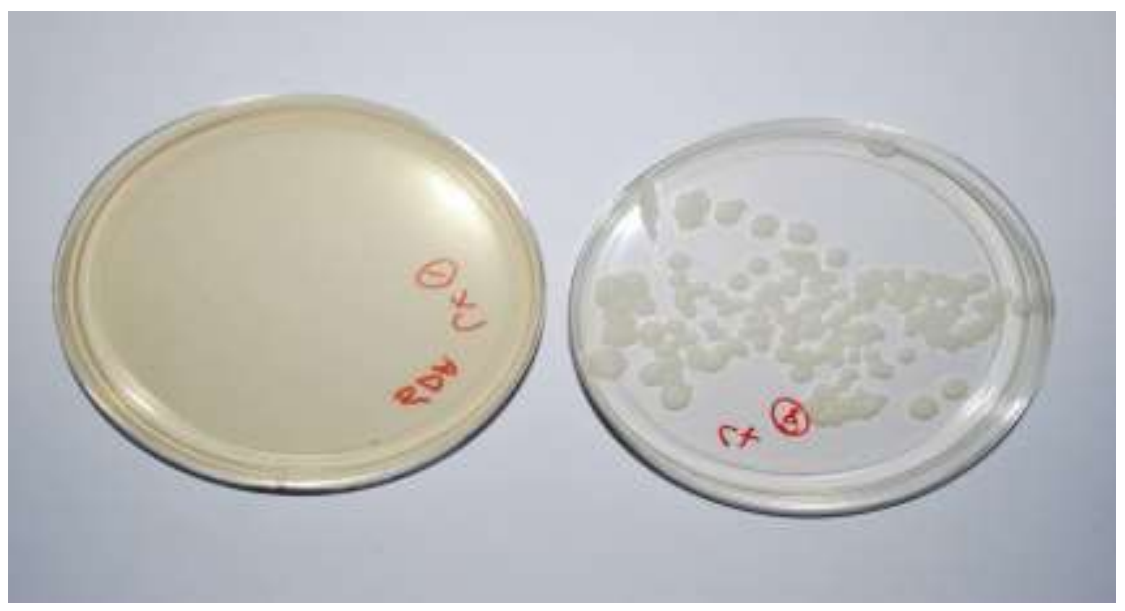

Fig.1. Chloroform extract of Nirgundi (Vitex nigundo) showing $100 \%$ inhibition compared to control

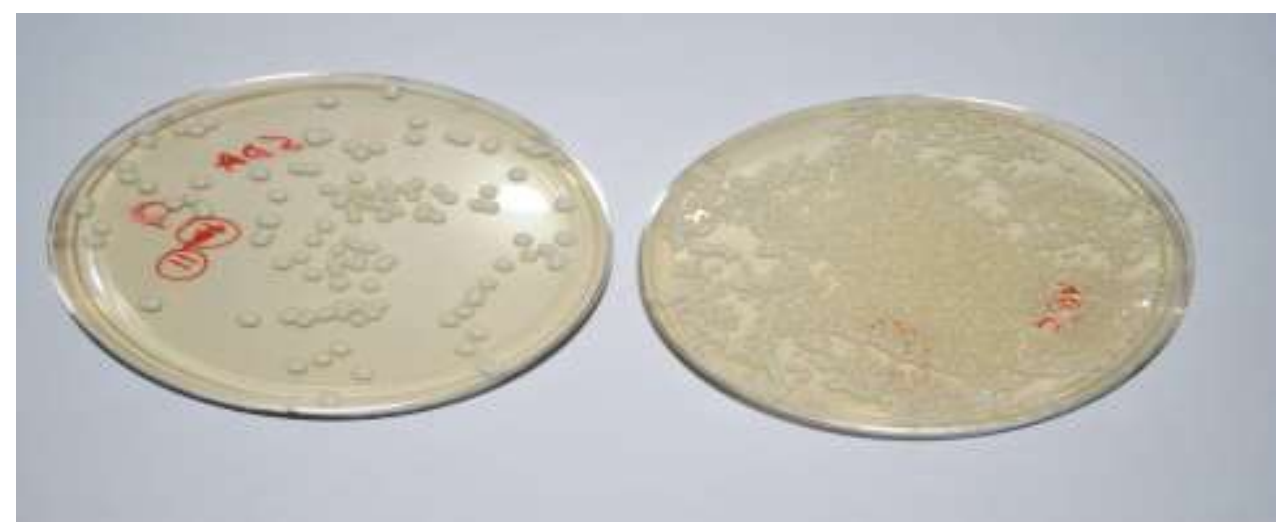


Usha Patil, International Journal of Ayurvedic \& Herbal Medicine 8(3) May.-June. 2018 (3207-3212)

Fig.2. Methanol extract of Nirgundi (Vitex nigundo) showing $75 \%$ inhibition of Candida albicans compared to control

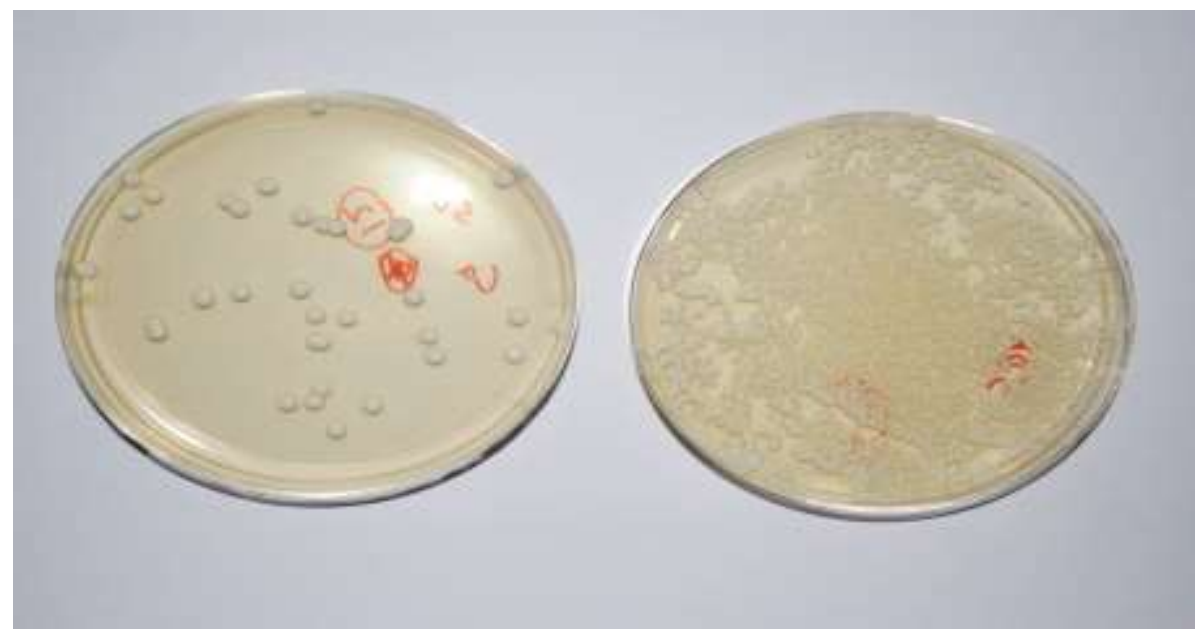

Fig.3. Ethanol extract of Nirgundi (Vitex nigundo) showing $75 \%$ inhibition of Candida albicans compared to control

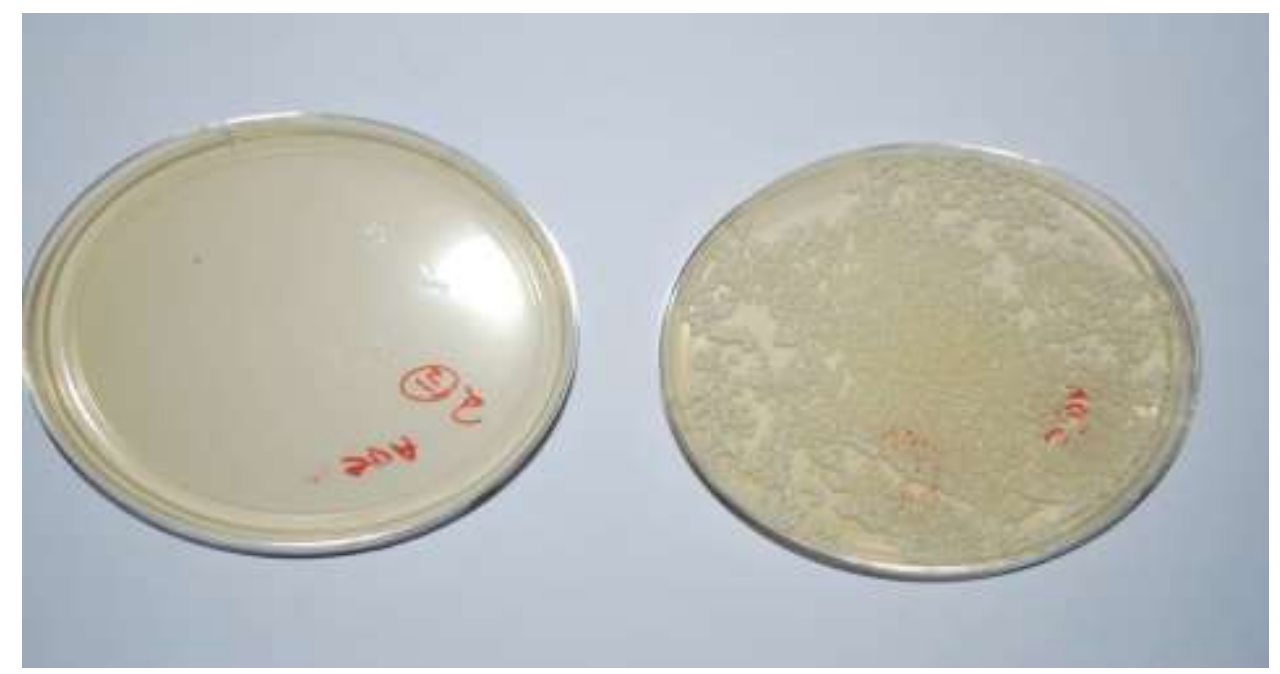

Fig.4. Chloroform extract of Nirgundi (Vitex nigundo) showing $100 \%$ inhibition of Candida tropicalis compared to control

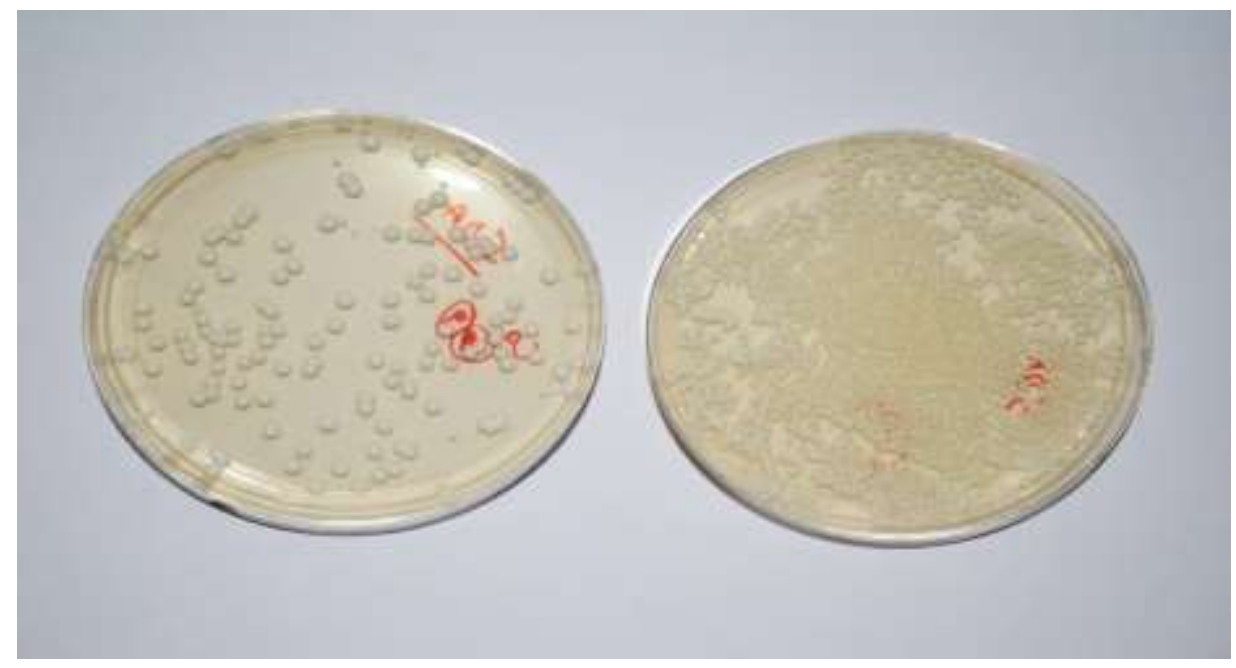


Fig.5. Methanol extract of Nirgundi (Vitex nigundo) showing $25 \%$ inhibition of Candida tropicalis compared to control

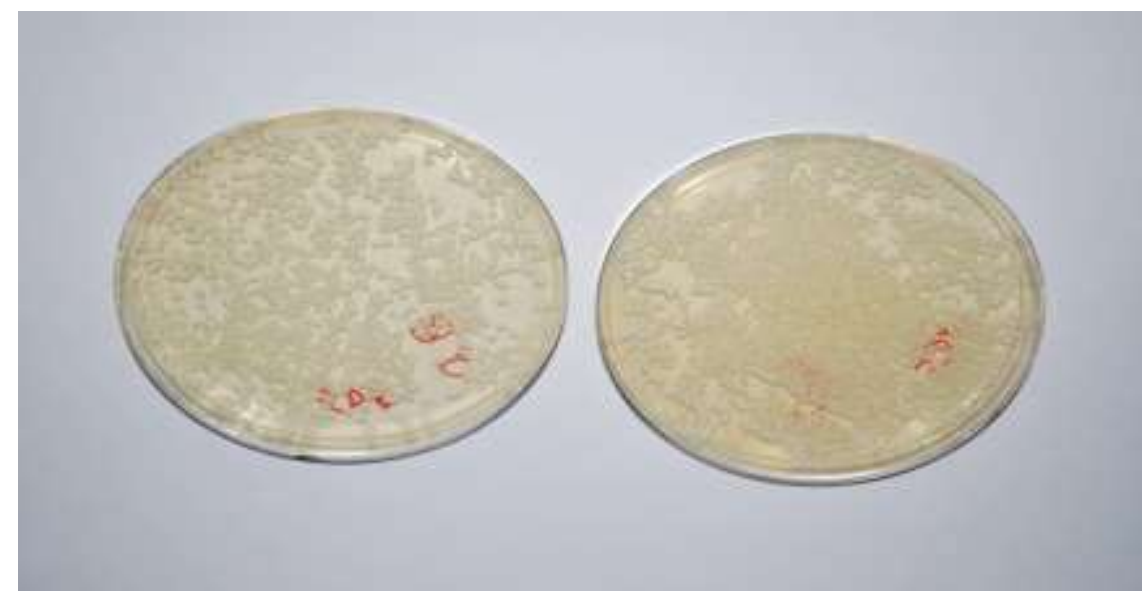

Fig.6. Ethanol extract of Nirgundi (Vitex nigundo) showing no inhibition of Candida tropicalis compared to control

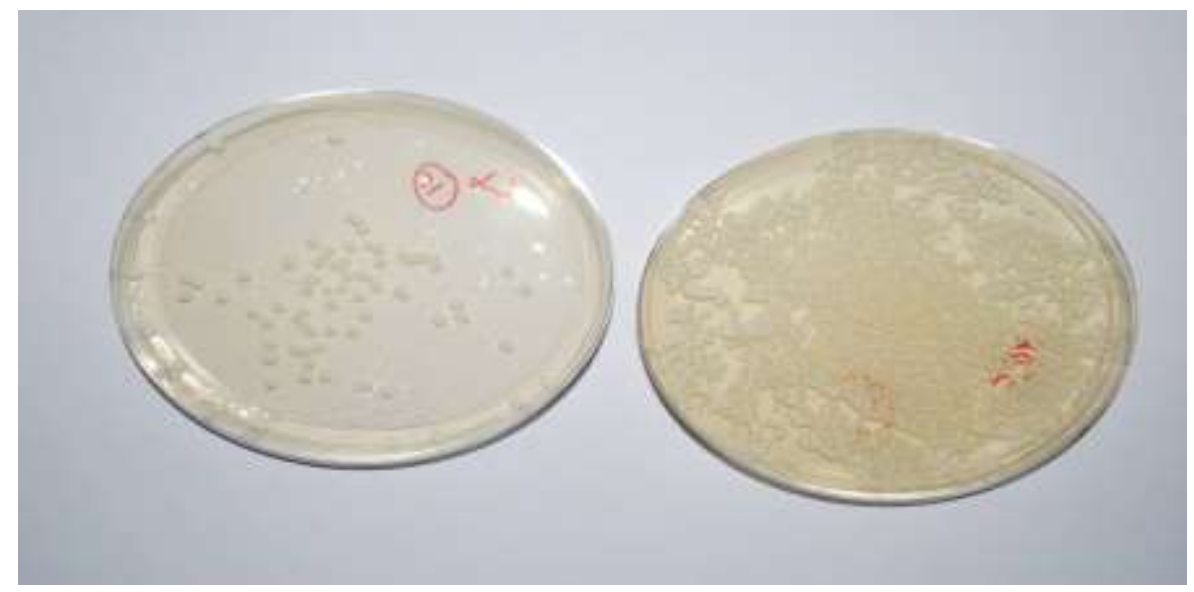

Fig.7. Methanol extract of Nirgundi (Vitex nigundo) showing $75 \%$ inhibition of Candida albicans compared to control

\section{REFERENCES}

1. Sushtruta.Suthrasthan.52/30

2. Astanga Hrudia.Cikistasthana.3/30

3. Dharmasiri MG, Jayakody JR, Galhena G, Liyanage SS, Ratnasooriya WD. Anti-inflammatory and analgesic activities of mature fresh leaves of Vitex negundo. Journal of Ethnopharmacology 2003; 87(2-3):199-206.

4. Diaz F, Chavez D, Lee D, Tan GT, Kardono LB, Riswan S et al. Cytotoxic flavone analogues of vitex carpin, from $V$. negundo. Journal of Natural Products 2003; 66(6): 865-867.

5. Chandramu C, Manohar RD, Krupadanam DG, Dashyantha RV. Isolation, characterization and biological activity of betulinic acid and ursolic acid from Vitex negundo L. Phytotherapy Research 2003; 17(2):129-134.I

6. Tandon V, Gupta RK. Effect of Vitex negundo on oxidative stress. Indian Journal of Pharmacology 2005; 37:38-40.

7. Hu Y, Zhang Q, Hou T, Xin H, Zheng H, Rahman K, Qin L. Estrogen-like activities in Vitex species from China determined by a cell based proliferation assay. Pharmazie 2007; 62:872-875. 
8. Sathiamoorthy B, Gupta P, Kumar M, Chaturvedi AK, Shukla PK, Maurya R. New antifungal flavonoid glycoside from Vitex negundo. Bioorganic and Medicinal Chemistry Letters 2007; 17(1):239-242.

9. Tandon VR, Khajuria V, Kapoor B, Kour D, Gupta S. Hepatoprotective activity of Vitex negundo leaf extract against anti-tubercular drugs induced hepatotoxicity', Fitoterapia 2008; 79:533-538.

10. Zheng CJ, Tang WJ, Huang BK, Han T, Zhang QY, Zhang H et al. Bioactivity-guided fractionation for analgesic properties and constituents of Vitex negundo L. seeds. Phytomedicine 2009; 16 (67):560-567.

11. Zhou YJ, Liu YE, Cao JG, Zeng GY, Shen C, Li YL et al. Vitexins, nature-derived lignan compounds, induce apoptosis and suppress tumor growth. Clinical Cancer Research 2009; 15(16):5161-5169.

12. Trease GE. Evans WC. Pharmacognosy. $12^{\text {th }}$ Edition 1983, Published by Bailliere Tindall, London.

13. Bergey DH, Krieg NR, Holt JG. Bergey's manual of systematic bacteriology. Williams \& Wilkins, (C)1984-C1989 Baltimore, MD 